\title{
Mastitis in Mediterranean Buffaloes
}

\author{
Jacopo Guccione* and Paolo Ciaramella \\ Department of Veterinary Medicine and Animal Productions, University of Napoli "Federico II", Italy
}

Submission: February 06, 2017; Published: May 30, 2017

*Corresponding author: Jacopo Guccione, Department of Veterinary Medicine and Animal Productions, University of Napoli "Federico II", Italy, Tel: +39081 2536001; Email: jacopo.guccione@unina.it

\section{Abstract}

Italy is the most important country where Mediterranean Buffaloes (MB) (Bubalusbubalis) and are bred (370'000 animals) for the production of buffalo Mozzarella cheese. This review article describes the clinical, diagnostic, epidemiological, prophylactic as well as bio security aspects of mammary infections in MB, based on the scientific date reported in literature. A comparison with mastitis of the cow is also reported.

Keywords: Mediterranean buffalo; Mastitis; Udder; Staphylococcus aureus; Vaccine

Abbreviations: MB: Mediterranean Buffaloes; PDO: Protected Designation of Origin; SCC: Somatic Cell Count; BMC: Bacteriological Milk Culture; TG: Treatment Group; DIM: Days in Milk; CG: Control Group; VG: Vaccinated; N-VG: Not-Vaccinated

\section{Introduction}

In Europe, there are approximately 440'000 Mediterranean Buffaloes (MB) (Bubalusbubalis) and Italy is the most important country where the seruminants are bred (370'000 animals). The reason for the increasing interest in buffalo breeding over recent years is the popularity of buffalo Mozzarella cheese (Protected Designation of Origin-P.D.O.) and almost lack of competition in EU-area for its type of cheese. Mediterranean buffaloes are typically reared in central and southern Italy, and $80 \%$ of Italian buffalo milk production originates from Campania region. Mediterranean buffalo's milk production is ranked 4th in the Italian agricultural economy concerning sales volume in the entire country (more than $€ 320$ million and more of 15'000 workforces). In Europe few animals are bred in Switzerland, Romania and Turkey but the milk production is essentially destined to their export or for local cheese production [1].

Although this ruminant represents a significant national economic resource for Italian rural agriculture, paradoxically only few and incomplete scientific knowledge is available and its management is often based on transferred knowledge from bovine scientific evidence because the two species have been considered similar for long time [2,3]. Dairy Mediterranean buffalo is characterized by an age at first calving ranging between 36-38months, a pregnancy, lactation and dry period of 10, 9 (240-270 days) and 4 months, respectively. Naturally the buffalo's heat is seasonal, and the calving is concentrated between December and March. Now many farmers use a de- seasonal system of calving to increase the milk production during the summer, when the mozzarella's request is higher. The mean milk yield is $1800-2200 \mathrm{~kg}$, although the improvement of breeding and genetic background has led to an increase in milk production up to $3500 \mathrm{~kg}$ per lactation.

Their udder is smaller than that of the cow, and the teats are longer and characterized by qualitatively stronger musculature in the proximal part of the teat canal than cows. The udder cisternal area $(22 \mathrm{~cm} 2)$ is smaller than that of the cow, with a lower restraining milk quantity (5\%vs. $20 \%$ in the cow), a collapsed lumen post milking and the largest milk fraction stored in the secretory tissue (95\%). The small volume of the buffalo cistern suggests that a longer teat stimulation before teat cup attachment is necessary to guarantee a correct oxytocin emission and a good milk letdown. The lag phase (between teat stimulation and milk let down) requires more time compared to cows, lasting on average 2 minutes. Careful teat preparation and pre-stimulation are important preconditions for successful buffalo milk letdown. Higher values of mechanic vacuum to milking the animals are required (at least $45 \mathrm{kPa}$ ) for successful milking of buffaloes [4-6].

MB mastitis is one of the most costly diseases causing great economic loss for the whole dairy-food chain. It is defined as an inflammatory reaction of parenchyma of the mammary gland of infective, traumatic or toxic nature, leading to changes in milk composition and coagulation properties as well as to a 
reduction in milk yield $[7,8]$. It is the result of the interaction between microbiological factors, host responses in the udder, and management practices. As in cows, poor hygiene and husbandry, overcrowding, bad ventilation, poor milking work and malfunction of milking machines can be considered the most important predisposing factors [9]

As in cow, mastitis is mainly caused by several contagious (S. aureus, Str. agalactiae), environmental (Str. uberis and dysgalactiae, Escherichiacoli, Enterobacteriacee spp. and yeasts) and opportunistic (Coagulase-Negative Staphilococci-CNS) bacteria. The episodes of mastitis are essentially observed during the first two months of milking in primiparous and pluriparous animals [10] S. aureus is the most important contagious pathogen in dairy MB. A recent study showed that $S$. aureus genotype B was the only one $S$. aureus strain isolated, with prevalence lower than observed in dairy cow (55\% vs $87 \%)$. As in cows, its presence is associated with an increase in Somatic Cell Count (SCC) and markedly reduced milk yield.

Clinical mastitis can present subacute, acute or chronic form. The most clinically clear forms (acute and chronic) can be diagnosed considering time of onset (sudden or progressive), observing local clinical signs (swelling, increase in quarter consistency, pain, etc), and/or less frequently systemic signs (fever, lack of appetite, weight loss, etc) or macroscopic anomalies of the milk (presence of blood, clots, pus, etc), as well as anatomo-functional anomalies of mammary tissue resulting in swelling, asymmetry, fibrosis and atrophy (chronic inflammations). The diagnosis of subclinical forms, on the other hand, is more difficult because in this case the udder and the milk do not show gross or evident anomalies, even though a high cell count can be observed. Even more for the infectious state, in other words those animals in which it is possible to isolate in-udder mastitogen bacteria with no signs that indicate a reactive state of the udder (low cell count). Finding of similar cases represents an important "alarm bell" for farmers and veterinarian with the goal to limit the spread of the problem by means of early diagnosis and opportune preventive strategies indirectly improving animal welfare and the safety of the entire dairy-food chain.

In this context, the use of diagnostic techniques in field is the only option to reach these goals. The international dairy federation, one of the most important worldwide institutes regarding dairy animals, considers the combined use of the bacteriological milk culture (BMC) and the SCC (i.e. polymorph nuclear leukocytes, macrophages, lymphocytes and epithelial cells), performed according to the corrected guidelines the gold standard for mastitis detection in dairy species. Diagnostic tests created for cows such as California mastitis test and electric conductivity, although clearly adaptable to farm practices, do not always guarantee enough sensitivity and specificity levels when used in buffalo and are therefore considered to be partially useful [11].
At present, SCC is an undisputed and well-established criterion for the evaluation of udder health and milk quality also in buffaloes. According to several studies, SCC $>200 * 103$ cells/ $\mathrm{mL}$ is currently accepted as a valid parameter to indicate an inflammatory mammary condition in dairy MB. Recent studies focused on differential cell counts of Mediterranean buffaloes' milk, showing a higher number in macrophages in the healthy udder as compared to cows, while similar trends have been observed for PMN cells between the two ruminants, both in healthy and mastitic animals $[12,13]$.

Mastitis treatment in buffalo is based exclusively on protocols created and scientifically proved for dairy cow. Although MB and cows are genetically different, drug administration for the two species follows the same rules (e.g. regarding type of drugs allowed, withdrawal time, etc). Since 2009, the EU legally included MB within the bovine specie (DGSA 01/02/2009), producing a practical use of drugs mainly based on personal experience of the veterinarian and on transferred knowledge from cows, but without any scientific evidence of their efficacy. Unfortunately, expensive, irrational and doubtfully efficient protocols are often performed in case of mastitis increasing costs for farmers and developing possible resistant and persistent bacteria strains in the farm.

However, recently, the systemic dry treatment with Penethamate Hydriodide revealed favourable results also in these ruminants. An intramuscular administration of this antibiotic was performed at $7 \mathrm{~d}$ precalving in a treatment group (TG), and ina control group (CG). Evening milk samplings were performed at 10,30 , and $60 \mathrm{~d}$ in milk (DIM). Somatic cell count (SCC) values were evaluated on composite milk samples, whereas bacteriological culture and California Mastitis Test were performed on quarter milk. Daily milk yields were recorded after all milkings. After 60 DIM, composite milk samples from each animal were collected for monthly SCC and bacteriological culture until drying off. Significant differences were found between the prevalence of mastitic quarters in the 2 groups at 10 and $30 \mathrm{DIM}$, and between the incidence of mastitic animals during the examined period (TG: $20 \%$ vs. CG: $50 \%$ ). Regarding the SCC and milk yields, significant differences were only found at 30 (SCC) and 60 DIM (milk yields). In this study, the antibiotic administration precalving showed good bactericidal activity against the most common udder-specific pathogens that cause mastitis in primiparous Mediterranean buffaloes, and greater efficacy was observed at 10 and 30 DIM compared with 60 DIM, showing that the use of this antibiotic could be economically beneficial in buffalo breeding.

However, according to the WHO (1998), other type of prophylaxis such as the use of vaccine administration on mastitis should be encouraged also in this dairy species. Recently the assessment of clinical efficacy over time of two different preventive vaccination protocols against S.aureus mastitis, has been described [12] vaccinated (VG) and not-vaccinated (N-VG) 
groups of 30 primiparous MB were selected from two different herds (herd A: VG1 and N-VG1; herd B: VG2 and N-VG2) of the same farm. Herd A received a double vaccination (Startvac $\AA$, 45 and 10 days before calving, protocol A), while in herd B an additional administration was performed (52 days after calving, protocol B). Bacteriological milk culture and assessment of somatic cell count (SCC) were performed at 10, 30, 60 and 90 days in milk (DIM) from composite milk samples. After 90 DIM, daily milk yields and SCC values were monthly detected until dry-off. The overall incidence of positive MB for $S$. aureus was $40.8 \%$ (49/120) in VG1 and 43.3\% (52/120) in N-VG1 (Protocol A), while $45.8 \%(55 / 120)$ and $50.8 \%(61 / 120)$ in VG2 and N-VG2 (Protocol B).

The latter was associated with a significant decreased in prevalence (at $90 \mathrm{DIM}$ ) and incidence of mastitis (animals positive for $S$. aureus, SCC $>200^{\wedge} 10^{3}$, with or without clinical signs) in the vaccinated $\mathrm{MB}$, while no difference occurred in protocol A. Moreover, herd B showed a significant reduction in prevalence of intramammary infection (animals positive for $S$. aureus, SCC $<200^{\wedge} 10^{3}$, no clinical signs) in the vaccinated MB at 60 DIM while no differences were detected in herd A, at any sampling time; N-VG2 had significantly higher overall SCC values than VG2 $\left(4.97 \pm 4.75\right.$ and $4.84 \pm 4.60 \log _{10}$ cells/mL \pm standard deviation, respectively), while no differences were recorded in herd A.This study showed encouraging results regarding reduction in mastitis and somatic cell count in mastitis of MB. Therefore the employment of vaccines represents an interesting challenge, even though its practical use should be advocated in association with a concurrent improvement of herd health management only, also in these ruminants.

\section{Conclusion}

In conclusion, although mastitis in buffalo can be considered a underestimated problem, the increasing national and international interest towards this ruminant, along with the increasing awareness of whom work in this field, can lead a significant improvement of udder health management, food safety and consumer protection, as consequence. Italy, as major buffalo milk producer in Europe, is showing great interest to resolve the problem also considering recent World Health Organization guidelines aiming to limit the use of antibiotics in all dairy species only to those having scientifically proved efficacy. The situation will force to plan ad hoc strategies of udder health managements specifically created for buffalo, introducing concepts as "selective treatment" and "mastitis prevention" also in Mediterranean buffalo medicine.

\section{References}

1. FAOSTAT (2014) Food and Agriculture data. Food and Agriculture Organization, Italy.

2. Guccione J, Carcasole C, Alsaaod M, D’Andrea L, Di Loria A, et al. (2016) Assessment of foot health and animal welfare: clinical findings in 229 dairy Mediterranean Buffaloes (Bubalusbubalis) affected by foot disorders. BMC Vet Res 12(1): 107.

3. Guccione J, Perreten V, Steiner A, Thomann A, Pesce A, et al. (2016) Short Communication: Role of Streptococcus pluranimalium in Mediterranean buffaloes (BubalusBubalis) with different udder health status. J Dairy Sci 99(4): 2945-2949.

4. Ambord S, Stoffel MS, Bruckmaier RM (2010) Teat anatomy affects requirements for udder preparation in Mediterranean buffalo. J Dairy Res 77(4): 468-473.

5. Guccione J (2013) Clinical and Diagnostical Aspects in Dairy Mediterranean Buffalo Mastitis. University of Study of Napoli Federico II, Italy.

6. Guccione J, Steiner A, De Rosa A, Ciaramella P (2014) Mastitis In Mediterranean Buffaloes: Is It Different To Cattle? SchweizerischeTierartztetage. Congress Centre Kursaal, Interlaken, Switzerland.

7. Guccione J, Pascale M, Ciaramella P (2013) La Mastite nella Bufala: imparare a conoscere e gestire una problematica ancora sottostimata 3: 5-8.

8. Guccione J, Pesce A, Pascale M, Tommasini N, Garofalo F, et al. (2014) Effects of Systemic Dry Primiparous Mediterranean Buffalo (BubalusBubalis). Treatment with PenethamateHydriodide on Udder Health and Milk Yields. J Dairy Sci 97(4): 2219-2225.

9. Guccione J, Cosandey A, Pesce A, Di Loria A, Pascale M (2014) Clinical Outcomes and Molecular Genotyping of Staphylococcus Aureus Isolated from Milk Samples of Dairy Primiparous Mediterranean Buffaloes (BubalusBubalis). J Dairy Sci 97(12): 7606-7613.

10. Guccione J, Perreten V, Steiner A, Thomann A, Pesce A, et al. (2016) Short Communication: Role of Streptococcus pluranimalium in Mediterranean buffaloes (BubalusBubalis) with different udder health status. J Dairy Sci 99(4): 2945-2949.

11. Schwarz D, Diesterbeck US, König S, Brügemann K, Schlez K, et al. (2011) Flow cytometric differential cell counts in milk for the evaluation of inflammatory reactions in clinically healthy and subclinically infected bovine mammary glands. J Dairy Sci 94(10): 5033-5044.

12. Guccione J, Pesce A, Piantedosi D, Salzano C, De Rosa A, et al. (2017) Efficacy of a polyvalent mastitis vaccine against Staphylococcus aureus on a dairy Mediterranean buffalo farm: results of two clinical field trials BMC Veterinary Research 13: 29.

13. Guccione J, Rubino V, Pesce A, Piantedosi D, Palatucci AT, et al. (2014) Diagnostic aspects of Mediterranean buffalo mastitis (BubalusBubalis) through the use of flow cytometric differential cells counts. In: XIX ANEMBE International Congress. Oviedo-Spain. 
This work is licensed under Creative Commons Attribution 4.0 Licens

DOI: 10.19080/JDVS.2017.02.555596
Your next submission with Juniper Publishers will reach you the below assets

- Quality Editorial service

- Swift Peer Review

- Reprints availability

- E-prints Service

- Manuscript Podcast for convenient understanding

- Global attainment for your research

- Manuscript accessibility in different formats

( Pdf, E-pub, Full Text, Audio)

- Unceasing customer service

Track the below URL for one-step submission https://juniperpublishers.com/online-submission.php 